\title{
Locus Terikat dalam Tarekat: Eksistensi Kampung Khalwatiyah Patte'ne di Tengah Urbanitas
}

\author{
Khilda Wildana Nur \\ Universitas Muhammadiyah Makassar, Makassar, Indonesia \\ nur.khildawildana@gmail.com \\ doi.org/ 10.29080/emara.v4i1.173
}

\begin{abstract}
An early Tasawwuf has already existed since Islam religion was first brought to Indonesia in which Tariqa traditions contributed to the spread of the faith. The Tariqa of Khalwatiyah Samman is one of the Islamic mysticisms which has developed and been in existence until now. The number of the Tariqa's followers reaches hundred thousand of people spread in various loci including Patte'ne village in Maros Regency, South Sulawesi. The strategic location becomes an urbanity anomaly toward the surrounding integrated area. The Patte'ne village promotes its existential identity as a consistent locus tied to Khalwatiyah Tariqa. The implementation of this can be seen in the spatial pattern of the area, in the cultural values reflecting the activities applied either in daily rituals or annually ceremonial agendas, and in the human resources acted as role models adopted from the Khalwatiyah teaching. The approach of this research uses both descriptive research and a historical approach. The methods of data collecting are surveys, visual materials, and observations. The result of this research indicates that a village will stand valuable if the concept of urbanity remains existent, in the form of both social and economic systems. The implication of those various sectors can create a condition and a balancing role for all the components creating the surrounding area. It demonstrates that the existence of Patte'ne village has become a locus which energizes an urbanity performance, which means that all the available resources have respectively participated so that it creates a mutually symbiotic relationship.
\end{abstract}

Keywords: village, Khalwatiyah, Patte'ne, tariqa, urbanity

\begin{abstract}
Abstrak: Tasawuf sejak awal telah ada sejak masuknya Islam di Indonesia dimana tradisi tarekat ini memberi andil dalam penyebaran agama Islam. Tarekat Khalwatiyah Samman adalah salah satu ajaran yang berkembang dan eksis sampai sekarang. Dengan jumlah Jemaah mencapai ratusan ribu orang, tarekat ini memiliki locus yang tersebar di berbagai daerah tak terkecuali di Patte'ne, Maros, Sulawesi Selatan. Letaknya yang strategis menjadi suatu anomali urbanitas terhadap kawasan terpadu di sekitarnya. Kampung Patte'ne mengeksistensikan identitasnya sebagai locus yang tetap terikat pada Tarekat Khalwatiyah. Implementasi ini dapat dilihat dari pola spasial kawasan, nilai-nilai budaya dalam aktivitasnya yang diwujudkan dalam beberapa ritual sehari-hari dan agenda seremonial tahunan, serta sumber daya manusia yang menjadi obyek teladan dari ajaran Khalwatiyah itu sendiri. Penelitian ini menggunakan pendekatan sejarah dengan bentuk penelitian deskriptif. Metode pengumpulan data yang digunakan, meliputi survei, materi visual dan observasi. Hasil dari penelitian ini didapatkan bahwa kampung akan tetap bernilai jika konsep urbanitas tetap eksis pada bentuk sistem ekonomi dan sosial. Implikasi berbagai sektor tersebut dapat bersimbiosis mutualisime pada unsur fisik dan non fisik pada kawasan dan lingkup sekitarnya. Kehadiran kampung Patte'ne ini memperdayakan potensi setempat menjadi lokus penggiat kinerja urbanitas.
\end{abstract}

Kata Kunci: kampung, Khalwatiyah, Patte'ne, tarekat, urbanitas 


\section{PENDAHULUAN}

Para pedagang Arab dan Gujarat merupakan pembawa syiar Islam di Indonesia termasuk dalam penyebaran aliran Tassawuf. Bentuk implementasi tassawuf dengan mencapai ma'rifat atau pengetahuan yang hakiki dengan menjadikan Muhammad SAW sebagai suri teladan. Dalam menggapai ma'rifat diperlukan suatu tarekat atau jalan dalam pelaksanaan ibadah yang diwariskan lintas generasi. Salah satu cabang tarekat yang eksis di wilayah Nusantara adalah Tarekat Khalwatiyah. Tarekat Khalwatiyah yang berkembang di pelosok Indonesia ini terdiri dari tarekat khalwatiyah yusuf yang dipelopori oleh Syaikh Yusuf Al-Makasari dan khalwatiyah samman oleh Muhamad Al-Samman (Malisi, 2015). Khalwatiyah Samman lebih terorganisir, memiliki pusat peribadatan sendiri namun memisahkan diri dari aliran lain, sementara Khalwatiyah Yusuf tidak memiliki tempat peribadatan khusus dan berasimilasi dengan masyarakat luas.

Pendiri tarekat Khalwatiyah adalah salah seorang Ahlul bayt Rasulullah SAW yang bernama Samman, Gauts Zaman Al-Waly Qutbil Akwan Syeikh Sayyidi Muhammad Samman Al-Qadiri Al-Quraisy Al-Khalwati Al-Madani. Setelah membentuk Zawiyah di Madinah dengan sejumlah murid dari Indonesia, aliran Khalwatiyah Samman berkembang ke Sulawesi Selatan melalui daerah Barru yang dibawa oleh Syeikh Abdullah Al-Munir dan kemudian dikembangkan oleh puteranya, bernama Syeikh Maulana Muhammad Fudail. Syeikh Maulana Muhammad Fudail kemudian mengamanahkan Syeikh Abdur Razak sebagai pelanjut (khalifah). Syeikh Abdur Razak kembali ke Maros $(1283 \mathrm{H})$ dan tinggal di kampung Paccele', Turikale, dan mulai mengajarkan tarekat Khalwatiyah Samman dan mulai mendekati lingkup Jemaah kerajaan di Sulawesi Selatan.

Setelah Syeikh Abdur Razak, ajaran Khalwatiyah berlanjut kepada tiga orang putranya. Putra tertuanya Syeikh Abdullah Puang Lompo menetap dan melanjutkan pengembangan tarekat ini di Leppakkomai. Pelanjut dari Syeikh Abdullah adalah putra-putranya yakni Syeikh Muhammad Saleh (Puang Lompo), Syeikh Muhammad Amin (Puang Ri NipaE) dan Syeikh Muhammad Ibrahim. Syeikh Abdullah kemudian bersama-sama Syeikh Muhammad Salahuddin KaraEng Turikale $V$ membuka areal hutan untuk permukiman baru yang kemudian diberi nama "Patte'ne".

Kampung Pattene inilah yang menjadi suatu kampung yang tetap eksis menjaga nilai kearifan lokal di tengah linkage kawasan urban. Eksistensi kampung merupakan kemampuan kampung untuk mempertahankan morfologi, fungsi, dan nilai-nilai. Ada dua faktor yang menjadi penyebab mengapa kampung mampu eksis di tengah-tengah pembangunan perkotaan dilihat dari faktor internal dan eksternal.
Faktor internal merupakan faktor fisik yang ada di dalamnya sedangkan faktor eksternal merupakan faktor non fisik yang terdiri dari pengaruh sosial dan ekonomi (Wahjoerini \& Setioko, 2014) Sebelumnya telah ada kajian tentang tarekat Khalwatiyah dengan fokus pada sejarah, perkembangan dan aplikasi ajarannya dalam masyarakat Islam di Indonesia. Pembahasan ini akan lebih mengetengahkan aspek budaya tarekat Khalwatiyah di Kampung Patte'ne dan aktivitas yang diwadahi dalam locus tersebut yang terkait pola spasial kampung dan hubungannya dengan kawasan sekitarnya dalam urbanitas yang berkembang saat ini. Kampung Pattene merupakan salah satu dari bentuk eksistensi kampung dalam konurbasi kota.

Fenomena kampung kota marak ditemui di negaranegara berkembang di Asia karena budaya bermukim masyarakat urban yang nonformal termasuk di Indonesia (Makhmud et al., 2017). Menurut (Wahjoerini \& Setioko, 2014), kampung kota merupakan akar budaya permukiman khas Indonesia dengan adanya beragam proses unik dilakukan oleh penduduknya. Kampung kota yang merupakan kawasan permukiman di perkotaan identitas yang dimilikinya sangat ditentukan oleh aktivitas yang dilakukan penghuninya. Terlebih lagi, kegiatan pembangunan dan pemanfaatan lahan di kampung kota bergantung pada tingkat ekonomi, karena umumnya masyarakatnya bergolongan ke bawah (Nurdiani, 2010). Menurut Nugroho (2009), ada beberapa prinsip yang dapat menjadi dasar dalam menciptakan kondisi urbanitas dan ruang kota yang berkelanjutan. Prinsip tersebut dijabarkan dengan menempatkan kampung kota sebagai bagian integral dari sistem perencanaan kota yang memiliki legalitas dan kepastian hukum terhadap eksistensinya melalui kekuatan politik menjadi dasar yang paling berpengaruh pada upaya perbaikan dan pengembangannya. Adaptasi dari new urbanism barat ke permukiman kampung disesuaikan dengan lokalitas struktur mikro kampung. Dengan adanya aspek legal dan konsep kampung, maka akan mensinergikan antar lingkungan baik melalui keterkaitan ekonomi, sosial maupun budaya (makro) maupun lingkungan fisiknya (mikro), sehingga dapat menciptakan sistem perkotaan dan memberi legitimasi kuat pada eksistensi kampung (macro - micro linkage).

Kampung adalah wujud proses dinamis sekelompok manusia yang terus berkembang seiring dengan pembangunan kota dalam transfromasi fisik spasial, demografi, sosial dan ekonomi (Lindarni \& Handayani, 2014). Kampung Patte'ne salah satu representatif dari gejolak perubahan tersebut. Dengan kekhasan kekhasan lingkup permukiman, beragamnya aktivitas, dan ekstrimisme bagian dari tata ruang kawasan sekelilingnya, maka kajian tentang eksistensi kampung Patte'ne ini penting untuk dilakukan. 


\section{METODE PENELITIAN}

Penelitian ini merupakan penelitian deskriptif dengan pendekatan sejarah. Penelitian kualitatif membuka jalan agar orang dapat menginterpretasikan realitas dari kehidupan sosial dengan mencari pemahaman akan pengalaman hidup seseorang. Strategi kualitatif berusaha untuk merakit bersama data yang mendalam (inpdepth account) tentang konteks sosial dengan menggunakan berbagai taktik (Groat \& Wang, 2013), Metode pengumpulan data yang digunakan, meliputi survei, materi visual dan observasi. Selain itu digunakan juga data sekunder berupa studi literatur dan instansi pemerintah. Metode analisis data yang digunakan dipakai metode synchronic reading dan diachronic reading.

Synchronic reading merupakan upaya membaca atau melakukan interpretasi secara sinkron, menyelaraskan berbagai informasi yang didapat pada saat yang sama. Sedangkan diachronic reading adalah penelusuran asal-usul sejarah yang berkaitan dengan obyek yang diteliti (Darjosanjoto, 2006). Selain itu juga digunakan Urban Design Toolkit yang dapat diaplikasikan dalam memahami konteks kota, melibatkan komunitas pendukung dan peka terhadap isu yang berkembang, dan lain sebagainya termasuk pengaturan manusia dan sumber dayanya, berupa character appraisal, survey, tissue analysis dan walkthrough analysis.

\section{HASIL DAN PEMBAHASAN}

\subsection{Locus Terikat dalam Tarekat Khalawatiyah}

Kawasan Religius Pate'ne berada pada wilayah administrasi Dusun Pate'ne, Desa Temmapaduae, Kecamatan Marusu, Kabupaten Maros. Delienasi fisik yang membatasi Kampung Khalwatiyah Pattene secara makro dengan wilayah administrasi lainnya berupa sungai Patte'ne dan gerbang dari arah Timur dan Barat yang terletak di Jalan Raya Patte'ne.

\section{a. Pola Spasial dan tata guna lahan}

Memasuki pusat wilayah spasial Kampung Khalwatiyah Pattene ini akan dijumpai gerbang yang secara garis lurus menuju masjid. Memasuki path ini, akan terhubung dengan lapangan sebagai sumbu pengikat yang menjadi ruang transisi sebelum memasuki masjid, area pemakaman, dan rumah pemangku tarekat yang digelar puang. Permukiman berorientasi ke jalan berderet mengikuti pola linear jalan (gambar 1). Permukiman Kampung Khalwatiyah Patte'ne terdiri dari beberapa elemen tata guna lahan yang meliputi lapangan, kompleks pemakaman, Masjid, permukiman warga, persawahan dan pergudangan.

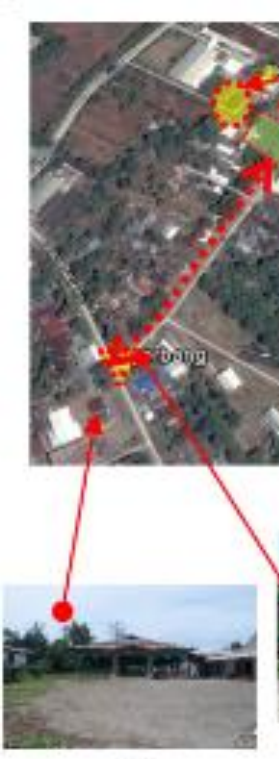

(a)

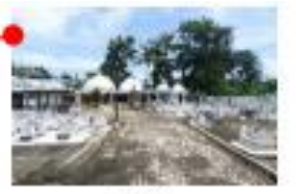

(e)

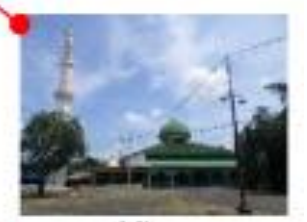

(d)

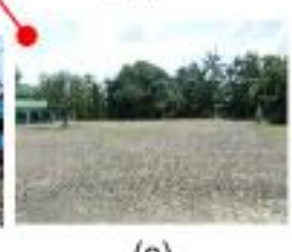

(c)
Gambar 1. Pola spasial kawasan Khalwatiyah Patte'ne (a)Kediaman tokoh khalifah (b)Gerbang pengarah ke lapangan (c)Lapangan sebagai ruang publik (d)Masjid; pusat kegiatan (e)Komplek pemakaman Khalwatiyah (Sumber: survey lapangan, 2016)

\section{Lapangan}

Lapangan menjadi ruang pengikat yang menghubungkan masjid, pemakaman dan koridor umum. Lapangan ini digunakan sebagai tempat menampung Jemaah pada saat agenda tahunan seperti hari raya led, Maulid dan juga sebagai tempat parkir. Mengacu pada konteks kampung, lapangan sebagai ruang terbuka berperang sebagai ruang pergerakan antar bagian dan luar kampung (Nugroho, 2010).

\section{Kompleks Pemakaman}

Kompleks pemakaman Khalwatiyah ini diperuntukkan khusus bagi pengikut tarekat dan para tuan tanah di Pattene. Jemaah Khalwatiyah memiliki keinginan untuk dekat dengan Puang. Pada pusat makam terdapat makam Puang Lompo yang berada dalam suatu rumah. Pemakaman ini juga telah dikavling oleh pengikut tarekat.
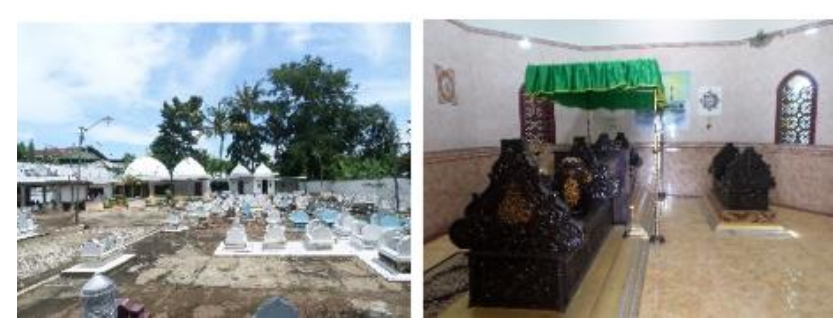

Gambar 2. Kompleks Pemakaman Khalwatiyah, Patte'ne (sumber: survey lapangan, 2016) 


\section{Mesjid}

Mesijd menjadi pusat aktivitas kegiatan dakwah pengikut tarekat. System peribadatannya dilangsungkan dengan integrasi metode tarekat dan budaya konvensional misalnya dzikir yang ekstatik (tidak sirr), dan penyampaian khutbah dalam Bahasa Bugis.

\section{Permukiman warga}

Tipologi permukiman warga sudah beragam, ada yang masih berbentuk rumah panggung, rumah batu dan ada gabungan keduanya. Unit rumah ada tetap menjadi rumah tinggal adapula berfungsi sebagai toko kelontong. Tipologi rumah panggung disinyalir berawal dari penyambutan KaraEng Masigi'na agar Syeikh Abdur Razak berniat tinggal di Maros. KaraEng Masigi'na membuatkan rumah panggung di SolojirangTurikale untuk tempat tinggal Syeikh Abdur Razak beserta keluarganya dengan kalampang atau lumbung padi dan sumur.

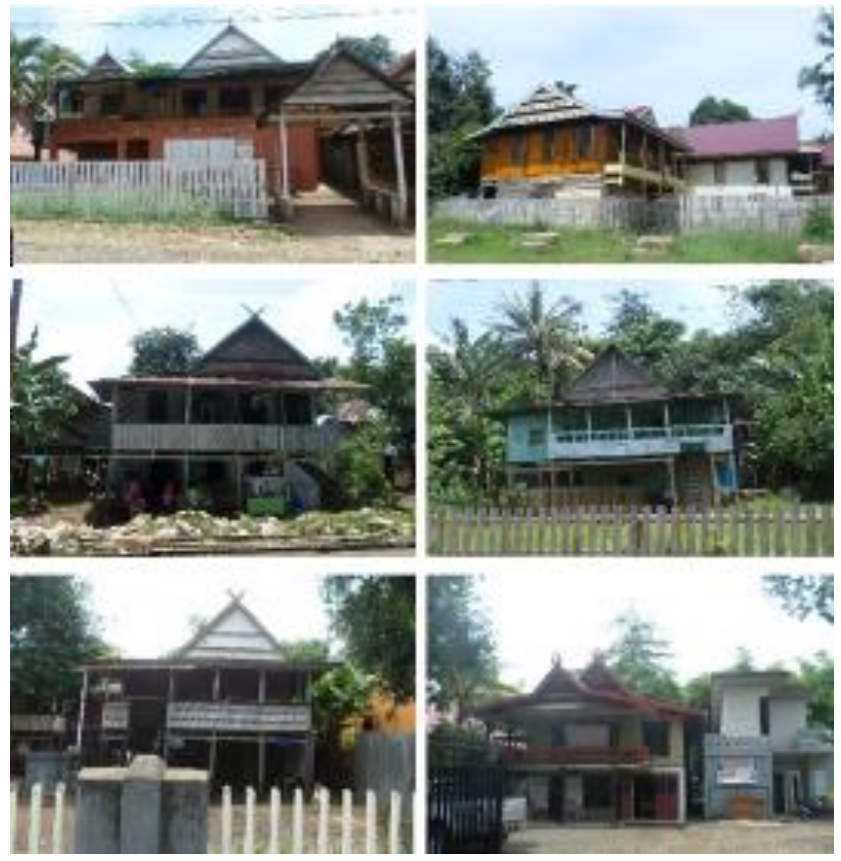

Gambar 3. Tipologi rumah panggung di kampung Khalwatiyah Patte'ne (sumber: survey lapangan, 2016)

Pada saat haul Maulid, rumah tinggal warga Pattene berubah menjadi tempat penginapan yang dapat diakses oleh tamu umum yang datang dari berbagai daerah. Unit permukiman ini menjadi obyek kunjungan pada hari raya Idul Fitri dan Idul Adha, khususnya rumah para pemangku tarekat yang digelar Puang.

\section{Persawahan}

Pada kawasan Patte'ne masih ada lahan persawahan yang belum dikonversi. Kepemilikan persawahan ini sebagian besar penduduk asli yang masih turunan dari puang khalifah dari Tarekat Khalwatiyah.

\section{Pergudangan}

Lokasi yang berdekatan dengan Kawasan Industri Makassar (KIMA) berimbas pada alokasi Patte'ne sebagai area pergudangan. Saat ini pemanfaatan area pergudangan telah dibatasi seiring konsolidasi pemerintah kabupaten dan warga setempat yang akan menjadikan kawasan khusus

\section{b. Ritual dan Seremonial}

Setiap tahun, Kampung Pattene menggelar haul akbar Maulid Nabi Besar SAW sekaligus memperingati penyebaran tarekat Khalwatiah Samman, Syeikh H. Andi Muhammad Saleh Puang Turu atau I Puang Lompo (1862-1967 M). Perayaannya tidak digelar tanggal 12 Rabiul Awal, tetapi setiap tanggal 20 Rabiul Awal tahun kalender Islam berjalan. Peringatan ini merupakan acara keagamaan yang dipadu dengan unsur ritual budaya. Jamaah Khalwatiyah Samman berdatangan dari beragam wilayah di Indonesia dan dari negara tetangga.

Pada saat maulid, perubahan tata guna lahanpun terjadi, dimana fungsi permukiman menjadi fungsi komersial (gambar 4). Para pedagang berbentuk linear menjajakan dagangannya dari pagi sampai tengah malam, tepat pada jalur yang dilintasi oleh pengikut tarekat. Bahkan pada saat seremonial haul berakhir pasar insidentil tersebut akan beroperasi 24 jam. Di sepanjang jalan menjadi walk-access for pedestrian.

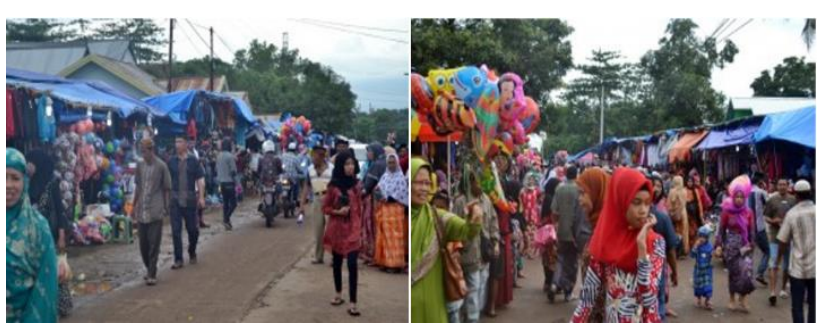

Gambar 4. Perubahan Tata Guna Lahan Jalan Poros Patte'ne menjadi koridor komersil (sumber: www.google.com, 2016)

Untuk pengikutnya sendiri, ada beberapa seremonial yang berlanjut diamalkan, semisal proses pembacaan doa disertai penyajian makanan di nampan baki yang diperuntukkan untuk malaikat rumah, untuk malaikat keselamatan akhirat dan seterusnya (gambar 5). Ritual keagamaan yang tetap dilestarikan antara lain "ma'barazanji", yaitu ritual tradisi pembacaan sejarah Rasulullah SAW, pembakaran pesse'pelleng (dupa) yang diletakkan di pintu rumah dan ritual pembacaan doa lainnya saat hajatan atau selamatan. Di kawasan Patte'ne dalam kehidupan sehari-hari maupun acara kebudayaan juga sering dijumpai olahraga sepak takraw pa'raga dan angaruq (tradisi penyambutan tamu). 


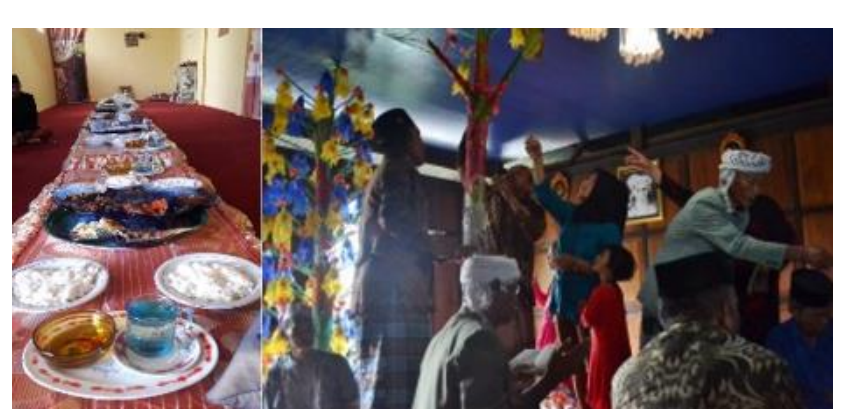

Gambar 4. Interior rumah Khalifah bentuk lesehan yang berorientasi pada perayaaan Haul dan Maulid (sumber: www.google.com, 2016)

\subsection{Eksistensi kampung di tengah urbanitas}

Meskipun wilayah administrasi berada di wilayah Kabupaten Maros, pergerakan dan aktivitas penduduk kawasan ini cenderung ke arah wilayah Kota Makassar. Hal ini sangat wajar mengingat letak kawasan yang sangat dekat dengan wilayah Kota Makassar, tepatnya di perbatasan wilayah Maros Makassar (gambar 5). Keadaan pola morfologi wilayahnya juga menunjukkan hubungan erat kawasan ini dengan wilayah Kota Makassar. Hubungan tersebut dapat dilihat dari kondisi akses utama kawasan ini yang terhubung langsung ke Jalan Tol Ir. Sutami, kawasan strategis maritim terpadu, kawasan bandara terpadu, kawasan pelabuhan Nusantara dan area transportasi jalur tol serta kebutuhan fasilitas umum bagi masyarakat dominan tersedia di wilayah Kota Makassar. Keadaan tersebut juga menyebabkan elemen ruang, pergerakan dan aktivitas Kawasan Patte'ne secara umum masih mendapat pengaruh dari perkembangan Kota Makassar.

Tipologi hunian kampung kota merupakan entitas pusaka kota dengan muatan konteks sejarahnya yang terlihat pada morfologi kotanya. Hal ini terlihat pada posisi Kawasan Pattene yang ditinjau dari Kota Makassar maupun Kota Maros. Kampung Patte'ne dengan segala pelaku dan aktivitasnya merepresentasikan kehidupan urban yang terjadi dalam gerusan waktu cepat atau lambat. Walaupun sebagai komponen pembentuk struktur kota yang terbentuk tanpa perencanaan yang matang atau berkembang sebelum adanya kebijakan perencanaan, keberadaannya dapat dikatakan sebagai penggerak urbanitas.

Kehidupan 'berkota' dalam agenda tahunan haul dan maulid di kawasan Pate'ne dibangkitkan dengan aktivitas religius yaitu ibadah shalat, tausiyah, dan dzikir akbar yang dilakukan selama sepekan. Perhelatan peribadatan ini cukup kontras dengan pergerakan aktivitas perekonomian dengan adanya ratusan stan-stan pedagang di sekitar tempat dzikir dan shalat. Aktivitas urbanitas ini menjadi simbol filosofi tentang hubungan dunia dan akhirat yang saling berdampingan.

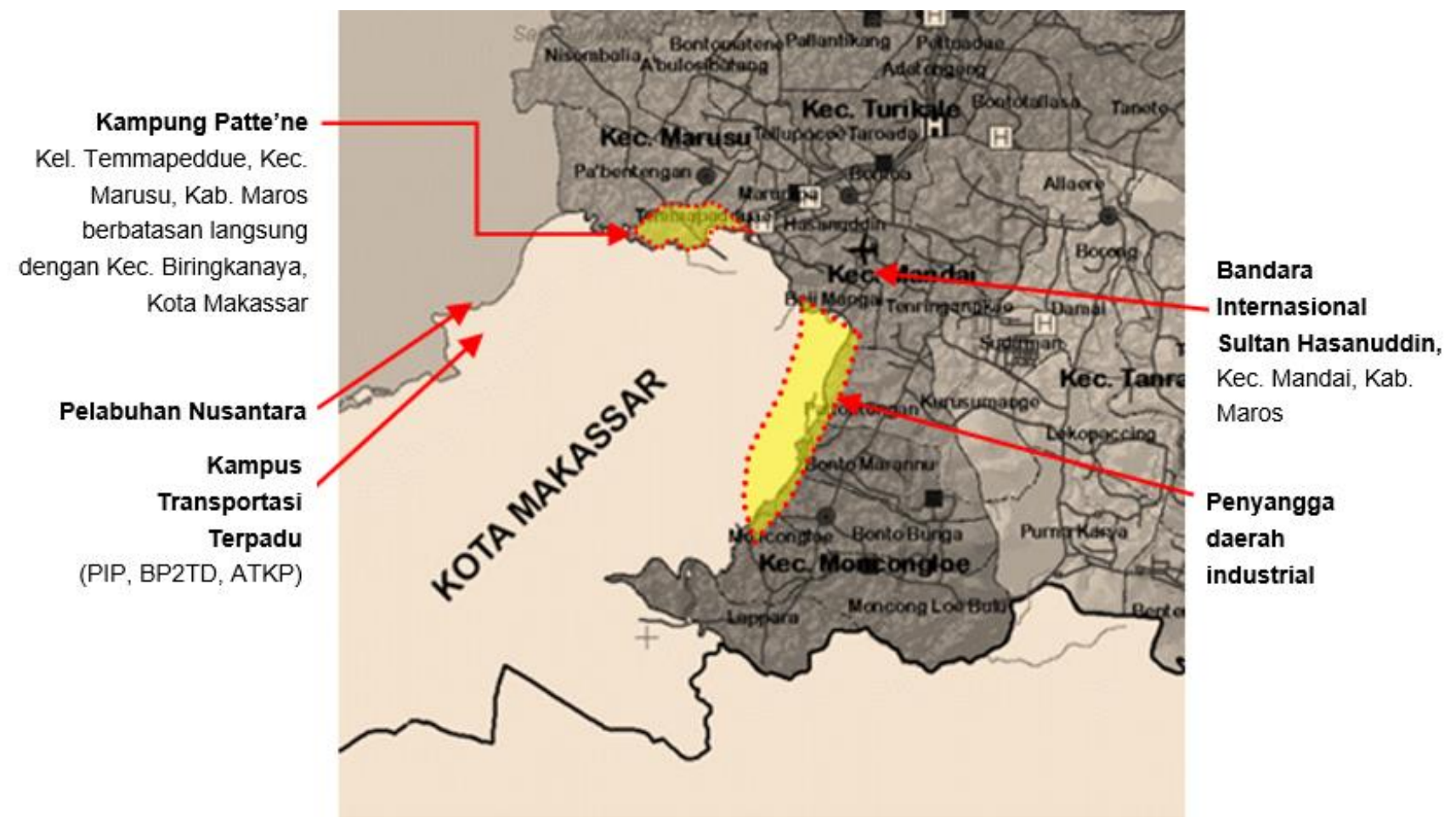

Gambar 6. Kawasan Patte'ne dan linkage (sumber: olah data lapangan, 2016) 
Jika melihat dalam lingkup pola spasial, besarnya perayaan tersebut tidak dibarengi oleh ketersediaan lahan dan akses yang cukup baik sebagai daya dukung kawasan religi (gambar 7). Kondisi tersebut di antaranya:

a. Terdapat ribuan orang beribadah dengan menggelar sajadah dari area masjid hingga ke jalan raya. Hal ini dikarenakan ruang terbuka tidak memadai untuk menampung jemaah.

b. Di sekitar lahan untuk beribadah dikelilingi stanstan pedagang yang berjualan, sehingga secara pemikiran dapat mengganggu kekhusyukan orang-orang yang beribadah.

c. Terdapat ribuan orang yang ingin berkunjung ke kawasan Patte'ne, namun hanya tersedia satu akses jalan utama. Keadaan tersebut mengakibatkan sering terjadi kemacetan yang panjang pada area jalan tersebut.

d. Lalu lintas jalan utama tersebut akan terpotong karena jalan juga digunakan sebagai tempat ibadah. Perubahan rekayasa lalu lintas saat Maulid berimbas sampai akses jalur tol-Trans Sulawesi dan jalan sekunder lain di sekitar kawasan.

e. Tidak terdapat ruang parkir yang baik, sehingga kendaraan pengunjung di parkir di halaman rumah warga atau lahan-lahan kosong di sekitar kawasan.

f. Fasilitas penginapan tidak tersedia untuk pengunjung saat perayaan haul. Namun hal ini tidak serta merta menjadi dampak negatif bagi kawasan, karena permukiman warga menjadi alokasi penginapan pengunjung untuk menjamu tamu yang datang tanpa meminta imbalan. Integrasi nilai kekeluargaan dan keakraban antara warga dan tamu / pengunjung merupakan implementasi dari ajaran tarekat. Hal tersebut juga menjadi adat istiadat dan juga ajaran agama yang harus dilestarikan dimana orang yang baik dan beriman akan menjadi unsur kenyamanan dan keamanan hingga tamunya itu pulang.

Pada dasarnya urbanitas tumbuh dan berkembang di lingkungan binaan yang berpotensi sebagai wadah bermukim penduduk. Corak kegiatan sosial, budaya, ekonomi terjadi untuk melangsungkan urbanitas membentuk sistem ekonomi dan sosial yang berkarakter dalam pembentuk elemen kota. Secara umum, kehadiran kampung dapat menjadi locus penggiat kinerja urbanitas, berkontribusi pada kawasan sekitarnya. Namun ini akan berbeda jika ditelaah dari pengaruh letak Kawasan Patte'ne, khususnya pada pola ruang mikro di sekitar kawasan Patte'ne yang memberi dampak bagi kawasan itu sendiri.

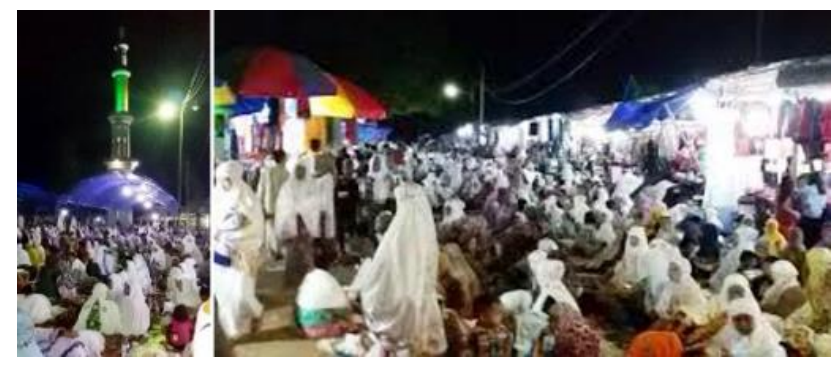

Gambar 7. Suasana perayaan Maulid di Patte'ne (sumber: www.google.com, 2016)

Sebagai contoh, pola ruang yang terbentuk dari kawasan pergudangan dan pabrik yang terletak tidak jauh dari Kawasan Patte'ne berdampak terhadap lingkungan dan sosial budaya kawasan. Potensi dampak lingkungan yang berimbas berupa polusi udara maupun tanah yang dihasilkan dari limbah pabrik atau gudang tersebut. Mengingat pada kampung Patte'ne masih terdapat beberapa hektar sawah warga yang berpotensi tercemar dari limbah pabrik atau gudang tersebut. Pada potensi dampak sosial budayanya, keberadaan pabrik dan gudang dapat memberi peluang kerja di sektor informal bagi masyarakat dan tumbuhnya permukiman berbasis kost-an bagi para pekerja di kawasan Patte'ne.

Kinerja kawasan Patte'ne yang memberi karakter dan mengeksplorasi ruh kearifan local terhadap linkage sekitarnya. Untuk mengarahkan dan menghidupkan eksistensinya, Kawasan Khalwatiyah Pattene ini telah ditetapkan dalam Peraturan Daerah Kabupaten Maros sebagai Kawasan Religius. Pada hakikatnya pemangku tarekat dan jemaah lebih memilih pola penataan ruang yang ditentukan oleh internal kawasannya. Kawasan terikat tarekat ini tidak memerlukan intervensi dalam dari geliat urbanitas dalam bentuk ekspansi diversifikasi fungsi lahan. Adapun yang menjadi aspirasi pemangku tarekat terkait pola spasial adalah penciptaan pola ruang berupa permukiman homogen yang diperuntukkan untuk Jemaah Khalwatiyah.

\section{KESIMPULAN}

Kampung Patte'ne tetap memegang teguh nilai-nilai kelokalan yang diinisiasi dari sejarah tarekat Khalwatiyah. Aktivitas yang dilandasi ajaran tarekat dan budaya lokal yang diwadahi dalam ruang kawasan menjadi unsur pembeda terhadap linkage sekitarnya. Ke depannya, eksistensi kampung Patte'ne dalam lingkupan sebagai kawasan khusus dapat menjadi destinasi berbasis wisata relijius dan sekaligus menjadi penggerak sektor perekonomian lokal dan lintas regional. Kampung Patte'ne berperan sebagai lokus penggiat kinerja urbanitas terhadap linkagenya. 


\section{REFERENCES}

Darjosanjoto, E. T. (2006). Penelitian Arsitektur di bidang Perumahan dan Permukiman. Surabaya: ITS Press.

Groat, L. N., \& Wang, D. (2013). Architectural Research Methods. John Wiley \& Sons.

Lindarni, D. A., \& Handayani, W. (2014). Transformasi Kampung Kota di Kawasan Segitiga Emas Kota Semarang. Riptek. Riptek, 8(2), 1-12. Retrieved from http://bappeda.semarangkota.go.id/v2/wpcontent/uploads/2015/08/1.-Transformasikampung-kota-dias.pdf

Makhmud, D. F., Nurhasanah, F., Utami, I. U., Khansha, S., Radnawati, D., \& Syahadat, R. M. (2017). Mewujudkan Kampung Bandan Sebagai Kampung Kota Berkelanjutan Menggunakan Pendekatan Asian New Urbanism. Vitruvian, 6(3). Retrieved from http://publikasi.mercubuana.ac.id/index.php/virtu vian/article/view/1540

Malisi, M. A. S. (2015). Tarekat Khalwatiyah. Tasamuh, 4(1), 2015.
Nugroho, A. C. (2009). Kampung Kota Sebagai Sebuah Titik Tolak Dalam Membentuk Urbanitas dan Ruang Kota Berkelanjutan. Jurnal Rekayasa, 13(3), 210-218. Retrieved from http://ftsipil.unila.ac.id/ejournals/index.php/jrekayasa/arti cle/view/20

Nugroho, A. C. (2010). Spatial Enclosure Sebagai Dasar Penataan Kampung Kota. JA! UBL, 1(1). Retrieved from http://jurnal.ubl.ac.id/index.php/ja/article/view/28 9

Nurdiani, N. (2010). Pola Pengembangan Rumah di Kampung Kota dan Faktor-Faktor yang Mempengaruhinya. ComTech: Computer, Mathematics and Engineering Applications, 1(2), 1041-1052. doi:10.21512/comtech.v1i2.2663

Wahjoerini, W., \& Setioko, B. (2014). Faktor-faktor yang Menentukan Eksistensi Kampung Pekojan sebagai Kampung Kota di Kota Semarang. Jurnal Pembangunan Wilayah \& Kota, 10(1), 106-114. doi:10.14710/pwk.v10i1.7637 